\title{
REABILITAÇÃO EDILÍCIA: UM DIÁLOGO SOCIAL
}

REHABILITACIÓN EDILICIA: UN DIALOGO SOCIAL

BUILDING REHABILITATION: A SOCIAL DIALOGUE

\author{
MARTINS, JULIANA CAVALINI
}

Mestre em Arquitetura e Urbanismo, Universidade Estadual Paulista "Julio de Mesquita Filho" - UNESP/Bauru, e-mail: arq.julianacavalini@hotmail.com

\section{SALCEDO, ROSIO FERNÁNDEZ BACA}

Pós-Doc em Arquitetura e Urbanismo, Universidade Estadual Paulista “Julio de Mesquita Filho" - UNESP/Bauru, e-mail: rosiofbs@faac.unesp.br

\section{RESUMO}

No Brasil, a indústria da construção civil é preparada para realizar obras novas, apresentando nesse quesito avanço tecnológico e controle na eficiência e gestão de qualidade, no entanto, no que diz respeito à reabilitação de edifícios, nosso país é incipiente, se comparado com alguns países europeus, onde existe um domínio e controle sobre a reabilitação de edifícios em todos os seus processos, que vão desde o planejamento e diagnóstico, até a execução e avaliação do uso social da obra. Com o envelhecimento do parque imobiliário edificado nos grandes centros urbanos brasileiro, inseriu-se, a partir dos anos 2000 nas agendas de debates políticos, a possibilidade de aproveitamento dos edifícios existentes nessas regiões os quais se encontram em estado de abandono e degradação. A exemplo de outros países, entende-se que esse estoque de edificações pode ser reabilitado e destinado ao uso de Habitação Social. Essa modalidade de intervenção, além de contribuir para a diminuição do déficit habitacional brasileiro, contribui também para a preservação do patrimônio arquitetônico edificado e renovação de áreas degradadas nos centros urbanos. Voltado para a proposta de ações de reabilitação edilícia, este artigo, através de um estudo de caso italiano, tem como objetivo mostrar como a experiência europeia poderia ser agregada às novas experiências brasileiras, a fim de melhorar a qualidade das intervenções habitacionais no Brasil. 0 diagnóstico se dá por meio do Método da Arquitetura Dialógica, entrevista com gestores do programa habitacional italiano e aplicação de questionários com os moradores do edifício estudado. A pesquisa mostra que a reabilitação de edifícios ociosos e/ou abandonados nas áreas centrais das nossas cidades seria uma estratégia política, social e urbana eficiente, pois, além de cumprir com a função social da propriedade, atenderia a demanda por habitação de uma grande parcela da população de baixa renda, excluída dos meios normais de compra e financiamento imobiliário, diminuiria consideravelmente o enorme déficit habitacional que existe atualmente, além de preservar o patrimônio arquitetônico e a ambiência dos centros urbanos.

PALAVRAS-CHAVE: reabilitação de edifícios; dialogia arquitetônica; habitação de interesse social.

\section{RESUMEN}

En el Brasil, la industria de la construcción es apta para realizar edificaciones nuevas, presentando avance tecnológico y control en la eficiencia y gestión de calidad en este aspecto, sin embargo, cuanto a la rehabilitación, el Brasil es incipiente si comparado con algunos otros países europeos, donde existe un dominio y control sobre la rehabilitación de edificios en todos los procesos, los cuáles van desde el planeamiento y diagnostico, hasta la ejecución y evaluación del uso social de la obra. Con el envejecimiento del parque inmobiliario edificado en los grandes centros urbanos brasileños, fue introducida en los debates políticos la posibilidad de aprovechamiento de las viviendas existentes en esas regiones que se encuentran abandonadas y degradadas. Al ejemplo de otros países, se entiende que estos estoques de edificaciones pueden ser rehabilitados y destinados al uso de vivienda social. Esa modalidad de intervención, allende contribuir para la disminución del déficit habitacional brasileño, contribuye también para la preservación del patrimonio arquitectónico edificado y renuevo de las áreas degradadas en los centros urbanos. Retornando para la propuesta de acciones de rehabilitación edilicia, este artículo, a través de un caso de estudio italiano, tiene por objetivo mostrar como la experiencia europea podría ser agregada a las nuevas experiencias brasileñas, con la finalidad de mejorar la calidad de las intervenciones habitacionales en el Brasil. El diagnostico se da por medio del Método de la arquitectura dialógica, entrevista con los administradores del programa de vivienda italiano y aplicación de cuestionarios con los moradores del edificio estudiado. La investigación muestra que la rehabilitación de edificios degradados o abandonados en las regiones centrales de nuestras ciudades son una estrategia política, social y urbana eficiente, pues, allende cumplir con la función social de la arquitectura, atendería a la demanda por vivienda de una gran parte de la población con renta baja, excluida de los medios normales de compra y financiamiento inmobiliario, disminuiría considerablemente el gran déficit de vivienda actual, además de preservar el patrimonio arquitectónico y la ambiencia de los centros urbanos.

PALABRAS CLAVES: rehabilitación de edificios; dialogía arquitectónica; vivienda de interés social.

\section{ABSTRACT}

In Brazil, the construction industry is prepared to carry out new works, presenting technological progress and control in efficiency and quality management in this regard, however, as far as rehabilitation is concerned, our country is incipient compared to some European countries, where there is a mastery and control over the rehabilitation of buildings in all its processes, ranging from planning and diagnosis, to the execution and evaluation of the social use of the building. With the aging of the buildings built in the great Brazilian urban centers, was included in the political debates the possibility of taking advantage of the existing dwellings in these regions that are in a state of abandonment and degradation. Following the example of other countries it is understood that these buildings can be rehabilitated and destined to the use of Social Housing. This modality of intervention, besides contributing to the reduction of the Brazilian housing deficit, also contributes to the preservation of built architectural heritage and renovation of degraded areas in urban centers. Aimed at the proposal of rehabilitation actions, this article, through an Italian case of the study, aims to show how the European experience could be added to the new Brazilian experiences, in order to improve the quality of housing interventions in Brazil. The diagnosis is given through the Method of Dialogical Architecture, interview with the managers of the Italian housing program and application of questionnaires with the residents of the building studied. The research shows that a rehabilitation of abandoned buildings in the central areas of the cities would be an efficient political, social and urban strategy to fulfill the social function of the architecture, besides meeting the demand for housing of a large part of the poor population, would reduce the housing deficit, in addition to preserving the urban architectural patrimony.

KEYWORDS: building rehabilitation; architectural dialogue; housing of social interest. 
O patrimônio construído é a acumulação de esforços herdados por uma sociedade que expressa seu desenvolvimento habitacional e a capacidade de investimento da comunidade através do tempo. Esse patrimônio é um capital concentrado, cujas possibilidades de aproveitamento através de operações de reabilitação, reciclagem e reutilização não podemos deixar de lado (GUTIÉRREZ, 1992).

Quando se fala de projetos e investimentos na área da construção civil brasileira, a reabilitação de edifícios é um tema que caminha pelas bordas das discussões políticas.

Discute-se muito sobre as gestões nos empreendimentos, os custos, a necessidade de desenvolver legislações específicas para esse segmento, o potencial e as demandas de mercado, no entanto, as iniciativas voltadas à reabilitação de edifícios ainda não representam uma parcela significativa nas pautas das reuniões e nos investimentos públicos, diferente do que acontece em alguns países europeus, tais como Itália, França, Inglaterra, Alemanha, Espanha, Portugal, entre outros.

A reabilitação de edifícios deveria estar no centro das pautas das políticas públicas, sobretudo como alternativa para a promoção de habitação popular, pois considerando a demanda por habitação social e 0 estoque de edifícios abandonados e degradados existente, principalmente nos grandes centros urbanos, esse estoque pode ser a chave, se não para a solução, ao menos a amortização do déficit habitacional que atinge a população de baixa renda em nosso país, ou seja, converter os edifícios abandonados em edifícios habitacionais por meio da reabilitação pode ser uma das alternativas para a questão habitacional.

Segundo Croitor (2008), o mercado europeu da construção, em 2005, foi responsável por movimentar 642 bilhões de euros. Desse total, aproximadamente $47 \%$ foram aplicados em obras de reabilitação de edifícios residenciais, pois consideraram essa categoria mais econômica e eficiente do que a demolição seguida de uma reconstrução ou uma construção nova.

Tal categoria de intervenção ganha ainda mais força quando considerados os edifícios localizados nos centros históricos ou grandes centros urbanos, pois, na maioria dos casos são edifícios antigos, degradados pela ação do tempo ou abandonados pela população local que se deslocou para as novas áreas de desenvolvimento da cidade, mas que expressam a história e a identidade do lugar. Por esse motivo, muitos países europeus vêem a importancia de se preservar tais edifícios e o caminho para essa preservação é a reabilitação.

Em São Paulo, a reabilitação de edifícios para habitação social tem como prioridade a revitalização da região central que entrou em decadência a partir da década de 1970.

No início dos anos 2000, foram criados programas públicos destinados ao aproveitamento do estoque imobiliário existente, dentre os programas destacam-se, por exemplo, o Programa de Arrendamento Residencial (PAR) e o Programa Morar no Centro, ambos destinados à reabilitação de edifícios para a população com renda mensal de até seis salários mínimos. No entanto, uma avaliação realizada em um destes edifícios reabilitados pelo PAR (Edifício Maria Paula), na cidade de São Paulo, mostrou que existem lacunas no Programa e que tais lacunas resultam em prejuízo para a qualidade dessas novas habitações.

De igual modo, na Itália existem programas públicos para reabilitação de edifícios, no entanto, esses programas estão avançados em suas estruturas legislativas e na prática de requalificação de áreas degradadas e reabilitação de edifícios, a exemplo do Programmi di Recupero Urbano (PRU).

Frente a essa constatação, este trabalho traz uma análise do Residencial San Basilio, implementado pelo Programmi di Recupero Urbano (PRU), na cidade de Roma, Itália, cujo objetivo é mostrar quais experiências desse estudo de caso italiano poderiam ser agregadas às experiências brasileiras atuais, a fim de melhorar a forma de intervenção destinada a conferir adequadas características de qualidade, desempenho, segurança e funcionalidade nos edifícios com potencial para serem reabilitados no Brasil.

A escolha do estudo de caso italiano se deu devido às estratégias de preservação consolidadas e bem sucedidas das instrumentalizações legislativas italiana, destinadas à reabilitação urbana e de edificações para habitação social, criado no âmbito de uma política habitacional em nível federal, atuante desde os anos 80 .

A avaliação do estudo de caso será apresentada através de uma leitura estruturada pelo Método da Arquitetura Dialógica, além dos resultados de uma entrevista com gestores do programa habitacional (PRU) e resultados de aplicação de questionários com os moradores do Residencial San Basilio. 
Em linhas gerais, o Método Dialógico está baseado nas teorias de Mikhail Bakhtin, Paul Ricoeur e Joseph Muntañola, os quais defendem que todo objeto arquitetônico possui uma dimensão histórica, pois está inserido em um contexto histórico, político, econômico e social e que todo elemento histórico depende do tempo e de um lugar, no qual a dialogia permite fazer a relação entre o objeto de estudo com o seu contexto (o ambiente, o entorno).

Dessa forma, o Método Dialógico permite uma leitura completa do objeto arquitetônico em três tempos: o tempo da prefiguração, ou seja, do projeto arquitetônico, o tempo da configuração, que diz respeito ao edifício reabilitado e a refiguração, correspondendo ao uso social do edifício, ou seja, entender o que os moradores pensam sobre a habitação que receberam.

O método é uma forma de avaliar a qualidade do morar e por isso considera também o contexto em que 0 edifício está inserido, ou seja, a ambiência ${ }^{1}$ urbana.

Com a leitura que o Método Dialógico proporciona, é possível avaliar se as propostas projetuais, as intervenções, o que recebe o morador e o espaço urbano dialogam entre si, entendendo que, se existe tal diálogo, a obra apresenta qualidade.

Os questionários aplicados aos moradores dos edifícios tiveram por finalidade conhecer a qualidade do ambiente reabilitado, saber se a moradia atende às necessidades das famílias, o que eles pensam sobre 0 local onde o edifício está inserido, entre outras questões relacionadas.

Por fim, foi realizada uma entrevista com um dos arquitetos da ATER-Roma envolvido com o Programmi di Recupero Urbano (PRU) para conhecer a demanda, o critério de escolha das famílias que receberam a moradia reabilitada e o processo projetual.

Todas as fotos apresentadas neste artigo é resultado de uma pesquisa in locu realizada pela autora.

Frente ao exposto, este artigo vem tratar não apenas da temática da reabilitação que, como já foi apresentado, é de extrema relevância para as questões patrimoniais e econômicas, mas tratará também da reabilitação de edifícios como promoção social, pois, como narra Bonduki (2014), "na história da arquitetura e urbanismo brasileiro, a habitação social sempre foi tratada como um objeto de segunda categoria diante dos edifícios monumentais e das residências da elite".

Em resumo, o tema apresentado é a reabilitação de edifícios e o objeto de estudo é a habitação.

O objetivo é mostrar quais experiências do programa habitacional italiano, experiente e consolidado, podem ser agregadas aos futuros programas de reabilitação habitacional brasileiro, ou seja, um modelo de iniciativa e ação pública para ser agregado às experiências de intervenções em nosso país, experiência esta tão importante, pois contribuiria para o aumento da qualidade de vida e diminuição do déficit habitacional da população de baixa renda nos grandes centros urbanos.

\section{POR QUE REABILITAR?}

Para discorrer sobre o tema cabe, antes de tudo, definir seu conceito.

O termo reabilitação é definido pelo Projeto Reabilita como sendo:

O processo pelo qual o imóvel ou bem urbanístico pode ser recuperado de maneira a contribuir não só para os moradores e proprietários do imóvel, como também em uma escala mais ampla, como um processo a interferir em toda uma área urbana (REABILITA, 2007, apud CROITOR, 2008).

Para Barrientos e Qualharini (2002), reabilitação é:

Reforma gerenciada de uma construção, visando a sua adaptação às novas necessidades dos usuários ou a otimização das atividades desempenhadas por ela com o objetivo de prolongar a vida útil da edificação, proporcionar a modernização de suas funcionalidades e promover a possibilidade de redução do custo de utilização, através da implantação das tecnologias disponíveis (BARRIENTOS; QUALHARINI, 2002). 
Atualmente, muitos são os questionamentos sobre qual seria a melhor ação, ou a mais viável: construir novo ou reabilitar?

Autores como Croito (2008), Jesus (2008), Rolnik (2007) entre outros, defendem que, considerando o aproveitamento da estrutura dos edifícios, a infraestrutura existente, a localização, o controle do espraiamento das cidades e o cumprimento da função social da propriedade, que desde a Constituição de 1988 nosso ordenamento jurídico entende que as propriedades devem cumprir uma função social e não ficar servindo de "engorda" para o setor imobiliário, fica claro que o ato de reabilitar edifícios é uma ação viável para o poder público, ainda mais quando se trata em converter o estoque imobiliário ocioso nos centros urbanos em habitação de interesse social, pois esta seria uma forma de controle de produção irregular de habitação nas áreas periféricas das cidades e melhoria na qualidade da habitação popular.

A reabilitação reduz o custo da moradia para o Estado, diferente do que ocorre com as construções novas, sobretudo em áreas periféricas, onde o poder público é obrigado a levar infraestrutura, onerando a implantação do projeto. Lembrando que, em se tratando de empreendimentos para habitação social, é fundamental pensar nas formas de economia de investimento, uma vez que os recursos destinados para tal são sempre limitados.

Segundo Silva (2004), reabilitar um edifício transforma a sua relação com a vizinhança. Além de atrair novos usuários para a região, modifica a paisagem urbana e proporciona melhoria da qualidade de vida dos habitantes locais.

Em 2017, o Plano Municipal de Habitação divulgou uma estatística mostrando o déficit habitacional da capital paulista. Mais de 369 mil famílias sem habitação e o parque imobiliário edificado e vazio na cidade, segundo o último censo do IBGE (2010), apontava para cerca de 290 mil imóveis vazios. Esses dados mostram que existe um problema a ser enfrentado e a reabilitação de edifícios na cidade seria uma alternativa para diminuir esse problema.

\section{CIDADE DEMOCRÁTICA: UM DIÁLOGO ENTRE O PASSADO E AS NOVAS EXIGÊNCIAS SOCIAIS}

Segundo o Estatuto das Cidades (2001), o Brasil, é um dos países que mais rapidamente se urbanizou em todo o mundo. Em 50 anos o país rural se transformou em um país eminentemente urbano, onde $82 \%$ da população moram em cidades. Esse processo de transformação do habitat e da sociedade brasileira produziu uma urbanização predatória e desigual.

As densas e grandes cidades se expandiram, formando regiões metropolitanas com extensas periferias ocupadas pela população pobre, expulsa das áreas centrais ou atraída de outros pontos do território brasileiro em busca de trabalho, renda e acesso a bens, serviços e equipamentos urbanos.

Hoje, os moradores das periferias continuam desprovidos de infraestrutura básica, cada dia mais distantes dos centros urbanos e ainda têm que enfrentar em seus obrigatórios deslocamentos para as áreas centrais 0 insuficiente e caro sistema de transporte (LABINUR, 2005).

Para Labinur (2005) a distribuição dos benefícios decorrentes do processo de urbanização é historicamente injusta e resultante de décadas de descaso, de incompreensão, de preconceito, e de atuação privilegiada, voltada apenas para alguns setores da cidade, e o quadro urbano atual se constitui em um dos maiores desafios neste século.

Como aponta Bonduki (2014), há mais de 100 anos, no Brasil, atuações sucessivas foram comprovadamente insuficientes para diminuir ou resolver as questões mais agudas da maioria da população brasileira, que é pobre, e vive precariamente em nossas cidades.

É frente a esta situação que este trabalho vem mostrar como seria possível, através de um exemplo eficiente e consolidado, melhorar a qualidade dos programas habitacionais para a população de baixa renda, no Brasil, tornando nossas cidades mais democráticas.

A consolidação de uma cidade democrática deveria ser o objetivo central da instrumentação de uma política urbana com gestores comprometidos efetivamente com a defesa do interesse geral acima dos particulares. Tal situação, normal nos países desenvolvidos, resulta um desafio de enormes proporções para os países de baixo nível de desenvolvimento, como o Brasil, onde a persistência da desigualdade e injustiça social coloca em crise a legitimidade das representações dos setores menos favorecidos e transforma o regime democrático em uma questão de aparência e não de essência (GHIONE, 2014).

Para Ghione (2014), as instituições democráticas estão constituídas, as leis são formuladas, mas os efeitos não chegam à sociedade e isso se manifesta cruamente nas precárias condições de urbanidade das cidades. 
A desintegração social se torna crítica quando os interesses setoriais e políticos definem políticas e leis que beneficiam uma parte minoritária e estimula a exclusão da maioria.

\begin{abstract}
$\mathrm{Na}$ realidade das cidades brasileiras, um compromisso essencial com a democracia deve estar relacionado com a liberdade de usufruto dos espaços urbanos, sem constrangimentos, com ofertas de mobilidade e acessibilidade qualificadas, e em brindar oportunidades de desenvolvimento social e pessoal a todos os cidadãos, sem distinção de classe social, condição econômica, racial, religiosa ou qualquer outra que impeça uma natural integração entre os habitantes de um conglomerado urbano (GHIONE, 2014).
\end{abstract}

Tal consideração objetiva um olhar crítico no modelo de cidade, especialmente nas periferias urbanas e nos grandes centros abandonados, onde está concentrado o maior nível de exclusão e carência de oportunidades de desenvolvimento. O conceito político de reparação social deve tanto orientar as estratégias de atuação urbana, como facilitar a acessibilidade e melhorar as condições de habitação.

Para Ghione (2014) um preconceito que merece ser superado é que pobre não merece arquitetura qualificada. Ao contrário, "só arquitetura e espaços públicos de qualidade poderão oferecer os lugares e soluções necessárias para elevar a autoestima social, dignificar os setores carentes e iniciar um processo efetivo de reconversão e reparação social". Só assim a democracia terá condições de ser considerada plena, com benefícios para todos os cidadãos.

Portanto, arquitetura qualificada para todos, sob diretrizes urbanísticas inteligentes e sensíveis é uma causa comprometida com a democracia e necessárias para construir uma cidade integrada e justa, ou seja, uma cidade democrática.

Não é possível pensar em uma cidade democrática se nos centros urbanos existe uma maioria carente sem oportunidades de desenvolvimento, se o direito de mobilidade se transforma em uma aventura cotidiana e a falta ou precariedade das habitações é assombrosa.

\title{
4 MÉTODO DA ARQUITETURA DIALÓGICA
}

O método da arquitetura dialógica, com base na dialogia de Mikhail Bakhtin é entendido como a relação cronotópica do texto (edifício) com seu contexto (lugar onde o edifício está inserido, seja ele urbano ou não), nas dimensões tempo-espaço de Paul Ricoeur (2003) caracterizadas por: prefiguração, configuração e refiguração e articuladas com as três dimensões dialógicas da topogênese de Joseph Muntañola que são a estética, a ética e a ciência.

No Brasil, as primeiras pesquisadoras a trabalharem com essa perspectiva metodológica foram as autoras deste artigo, cujo primeiro trabalho produzido foi a dissertação de mestrado de Martins (2016), com co-tutoria de Joseph Muntañola pela Universitat Politècnica de Catalunya, Barcelona/Espanha.

Atualmente, um grupo de estudos liderado por Rosio F.B. Salcedo, na FAAC/UNESP, campus de Bauru, dá continuidade à pesquisa sobre o Método Dialógico.

Neste Método, a analogia da concepção dialógica com a arquitetura é construída por Joseph Muntañola.

Nesta pesquisa, parte-se da ideia de que o objeto arquitetônico possui uma dimensão histórica, pois está inserido em um contexto histórico, político, econômico e social.

Entende-se também que todo elemento histórico depende do tempo e de um lugar, no qual a dialogia permite fazer essa relação entre o edifício com o seu entorno.

Para fazer essa leitura histórica e entender se o edifício dialoga com o entorno, tomou-se como roteiro as fases da hermenêutica de Paul Ricoeur (2003) que definem os três tempos básicos de uma obra, que são:

1. Prefiguração: Diz respeito ao projeto arquitetônico original. O que pensaram os arquitetos, os idealizadores da obra, as necessidades da época em quem o edifício foi projetado.

2. Configuração: A construção do edifício ou a reabilitação. Entender se o projeto foi executado exatamente como proposto ou se houveram alterações.

3. Refiguração: Diz respeito ao uso social da obra, ou seja, a opinião das pessoas que utilizam o espaço projetado e edificado. Nessa fase é possível entender se o projeto levou em consideração as necessidades dos usuários ou não. 
No entanto, para realizar a análise dialógica, através das três fases ricoeurianas foi necessário definir elementos/critérios capazes de analisar detalhadamente o objeto de estudo em cada uma das três fases.

Esses elementos foram encontrados na topogênese de Muntañola que afere o objeto arquitetônico baseado na ciência (fundamentação teórica, tecnologia), na estética (que retira do lugar as forças que impulsionam a criação do projeto) e na ética que revela o saber fazer, o fazer bem feito pelo arquiteto.

Dessa forma, a dialogia de Bakhtin, as fases da hermenêutica de Paul Ricoeur e os critérios de interpretação dados pela topogênese de Muntañola, constituem o Método da Arquitetura Dialógica (Tabela 1), que em sua totalidade, permite a leitura e a compreensão de obras arquitetônicas.

Tabela 1: Síntese do Método Dialógico

\begin{tabular}{|ccc|}
\hline BAKTHIN & RICOEUR & MUNTANOLA \\
\hline Dialogia & Hermenêutica & Topogênese \\
\hline $\begin{array}{c}\text { Estabelece a relação entre o texto } \\
\text { (edifício) e seu contexto (entorno). }\end{array}$ & $\begin{array}{c}\text { Analisa o texto e o contexto através } \\
\text { dos tempos de uma obra. }\end{array}$ & $\begin{array}{c}\text { Cria critérios de análise para cada } \\
\text { tempo da obra. }\end{array}$ \\
\hline
\end{tabular}

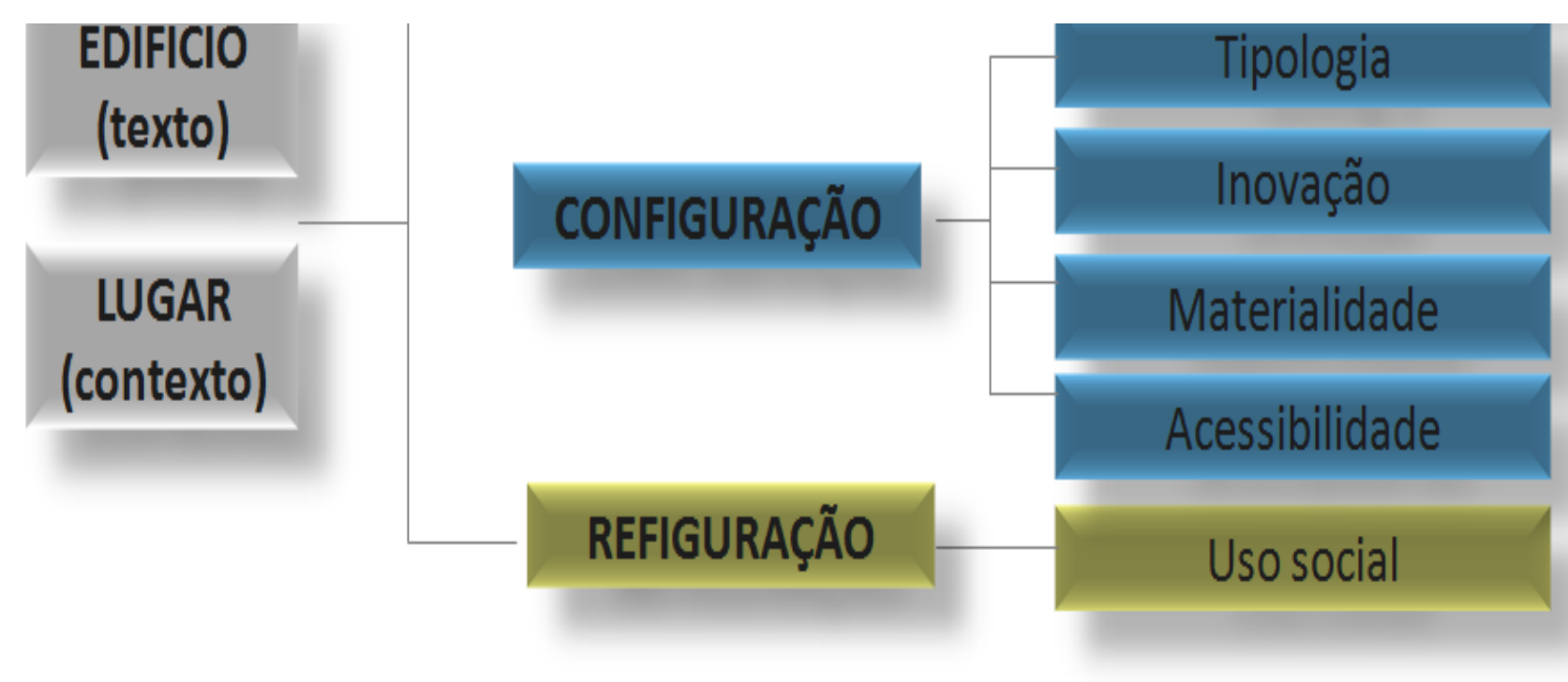

Fonte: Produzido pela autora.

\section{REABILITAÇÃO DE EDIFÍCIOS NA ITALIA: APRENDENDO COM EXPERIÊNCIAS CONSOLIDADAS}

A crônica carência de habitação social também constitui uma parte relevante e morfologicamente reconhecível dos centros urbanos consolidados na Itália.

Segundo o Censo FEDERCASA (2008), com um estoque de aproximadamente 940 mil habitações populares produzidas até os dias de hoje na Itália, aproximadamente 768 mil moradias foram adquiridas por meio de programas de reabilitação edilícia.

Segundo Trusiani (1999), na Itália, a gestão pública na área habitacional busca um sistema articulado entre os setores público e privado. Embora essa relação público/privado não seja desejada, ela é reivindicada, tornando-se o elemento estruturante de todo o processo, bem como a condição indispensável para iniciar toda a operação de requalificação urbana e reabilitação de edifícios. Tal cooperação se traduz na oportunidade de aumentar a disponibilidade financeira e melhorar a eficiência da administração pública por meio da organização, comunicação, transparência, investimentos, fiscalização, etc.

Segundo o arquiteto Roberto Fantastichini da ATER-Roma (Azienda Territoriale per l'Edilizia Residenziale pubblica del Comune di Roma), envolvido com o desenvolvimento do Programmi di Recupero Urbano (PRU), objeto de estudo deste trabalho, em uma entrevista realizada pela autora no dia 09/04/2015 relata que, nos 
primeiros anos da década de 1990 uma nova fase de planificação urbanística foi constituída pela Lei $n^{\circ}$ 457/78, inciso IV que previu na recuperação do patrimônio edificado e degradado um novo tipo de instrumentalização urbanística. Essa Lei passou a regulamentar as zonas não edificadas e a redisciplinar realidades territoriais e urbanas edificadas, atuando por meio de Programas habitacionais, dentre eles o Programmi di Recupero Urbano (PRU), um programa nacional, gerido pelo Ministério Público do Trabalho que constitui um instrumento urbanístico executivo e sistemático que atua por meio de um conjunto de ações coordenadas, sobre as temáticas da urbanização, o meio ambiente e o meio edilício.

Segundo Roberto Fantastichini, os objetivos do PRU são: a criação, a manutenção e a modernização das obras de urbanização primária e secundária, com especial atenção para os problemas de acesso às redes de transporte público e acessibilidade urbana. Visa melhorar a qualidade da paisagem urbana, por meio da inclusão de mobiliários urbanos adequados, preservação das áreas verdes, a recuperação e reabilitação de edifícios com obras de manutenção, restauração, renovação conservadora, reestruturação, modernização e integração da habitação com o ambiente urbano.

Trusiani (1999) ressalta que o PRU não se limita a avaliar e/ou buscar apenas a qualidade interna da habitação, mas também a qualidade do contexto urbano, por meio de ações integradas.

Fantastichini relata ainda que, a atuação do PRU considera a qualidade da intervenção, seja em nível arquitetônico e/ou urbano, evidenciando que a ação não pode ser caracterizada como uma operação aritmética, mas o resultado de uma série de considerações tais como: compatibilidade econômica, relação custo/qualidade e fator ambiental.

O Programmi di Recupero Urbano (PRU) destina-se às seguintes categorias da população: sem-teto ou com alojamento precário, famílias com problemas habitacionais graves, pessoas que são assistidas pelos serviços sociais, portadores de deficiência física, pessoas com mais de 65 anos, famílias com 3 ou mais filhos dependentes, jovens casais, mãe solteira com pelo menos 1 filho dependente, família muito numerosa, habitar com mais de 1 núcleo familiar dentro da mesma residência, famílias despejadas e estudantes que não são beneficiados por um apoio financeiro.

$\mathrm{Na}$ entrevista, foi revelado que o valor da habitação, pago pelos moradores, varia de acordo com o tamanho da habitação e de acordo com a renda familiar. Estão incluídos no valor das prestações o pagamento de água, energia e aquecimento de ambiente. Por lei, cada família só pode investir até $17 \%$ da renda mensal com o pagamento da moradia.

Com relação às tipologias habitacionais, em casos de reabilitação ou reforma de edifícios, o PRU admite áreas construídas de até $120 \mathrm{~m}^{2}$.

Dessa forma, pode-se dizer que o programa habitacional (PRU), desenvolvido na Itália, não atua de forma pontual no problema, mas trata de um saneamento do território, prevê a recuperação do tecido construtivo, além de intervenções de requalificação e renovo urbano global que reorganizam as funções, as atividades e os equipamentos no contexto urbano da cidade, favorecendo automaticamente a qualidade dos edifícios que serão reabilitados e também daqueles que não precisam de intervenção, ou seja, promove uma relação dialógica entre edifício e contexto urbano.

\section{Reabilitação de edifício habitacional: Residencial San Basilio}

O Residencial San Basilio é um exemplo de intervenção edilícia pública, realizada através do Programmi di Recupero Urbano (PRU) em Roma, na Itália.

Esse estudo de caso será apresentado de acordo com a estrutura de leitura projetual definida pelo Método Dialógico. Esse Método é uma forma de avaliar a qualidade do morar.

\section{Prefiguração}

O Residencial San Basilio data do ano de 1954 e está localizado no contexto do Bairro San Basilio, centro urbano consolidado da cidade de Roma (Figura 1). 
Martins, J. C.; Salcedo, R. F. B.

Figura 1 - Planimetria geral do Residencial San Basilio inserido na malha urbana de Roma.

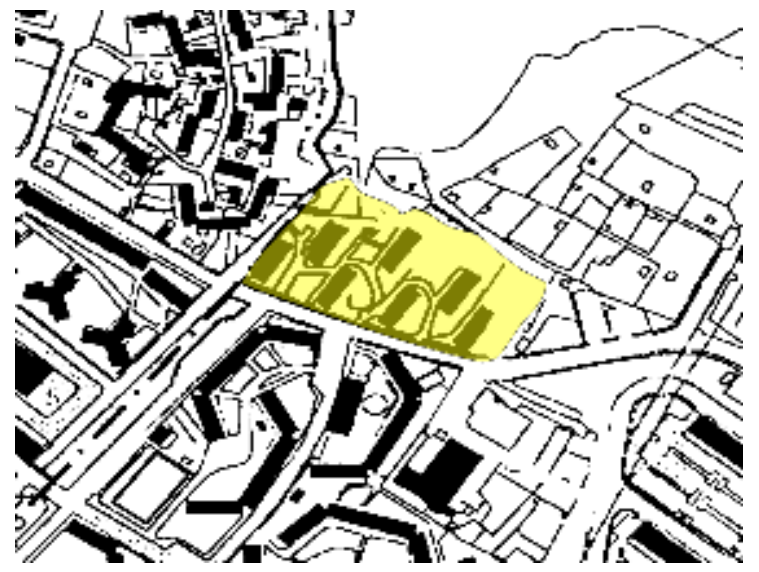

Fonte: Mencagli (2011), adaptado pela autora.

O residencial é composto por sete edifícios (Figura 2) de quatro pavimentos, avarandados, de estilo modernista, dispostos espacialmente em blocos lineares, classificados como "palazza", (construção econômico-popular da tradição romana) (Figura 3).

Figura 2 - Planimetria geral do Conjunto Residencial San Basilio com seus sete blocos em diagonal

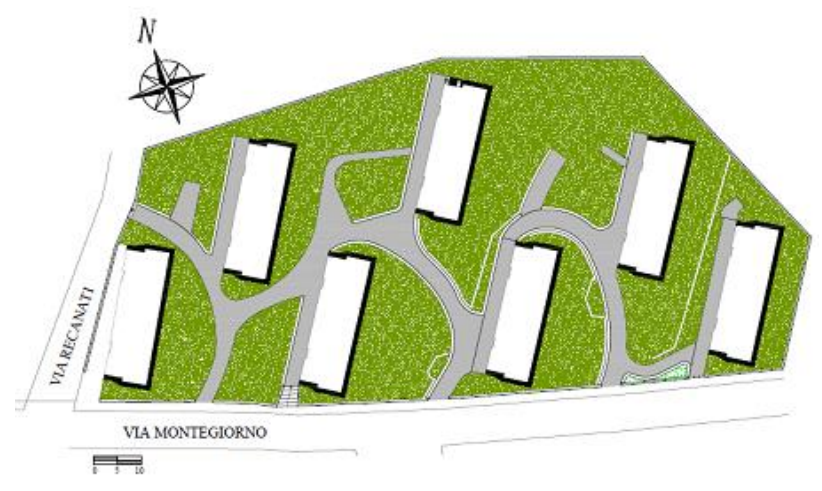

Fonte: ATER - Roma (2015), adaptado pela autora.
Figura 3 - Conjunto Residencial San Basilio

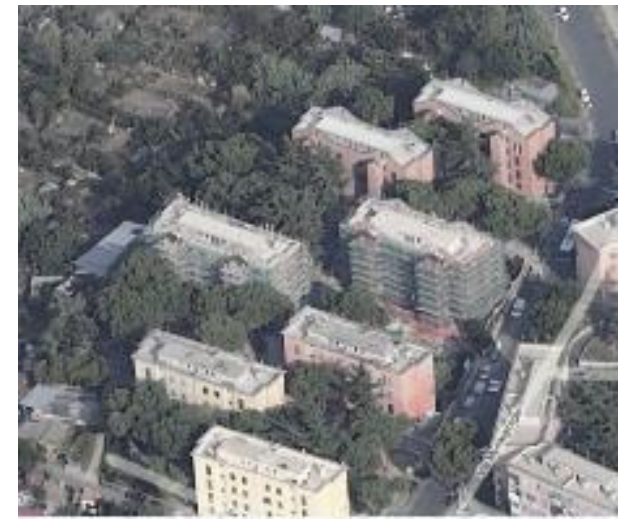

Fonte: ATER - Roma.

Todos os blocos foram construídos com alvenaria portante, sem revestimento externo, piso cerâmico $20 \mathrm{~cm} \mathrm{x}$ $20 \mathrm{~cm}$ nas áreas de circulação, escadas em concreto polido, portas e janelas de madeira e pedra retangular de concreto na área externa do edifício. A cobertura foi construída com laje impermeabilizada e revestida com piso cerâmico (Figuras 4 e 5).

Figura 4 - Fachada leste original, antes da reabilitação

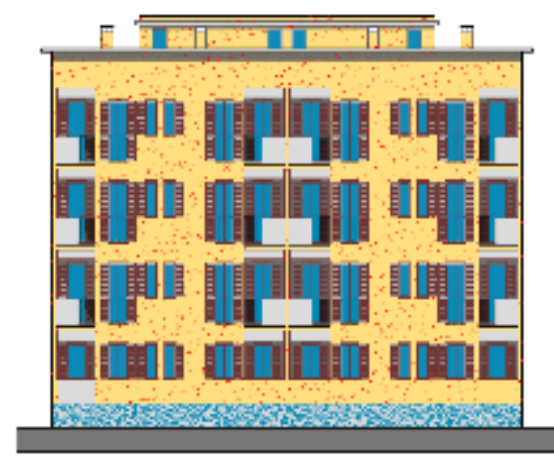

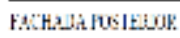

FT

Fonte: ATER - Roma (2015).
Figura 5 - Fachada Oeste original, antes da reabilitação

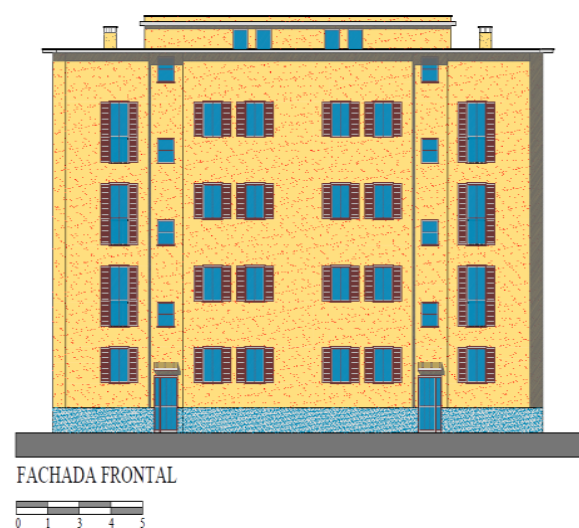

Fonte: ATER - Roma (2015). 
Martins, J. C.; Salcedo, R. F. B.

O San Basílio foi prefigurado e configurado com duas tipologias de habitação: com dois e três dormitórios, sala, cozinha, banheiro e varanda.

As áreas por apartamento variam de $39 \mathrm{~m}^{2}$ a $52,8 \mathrm{~m}^{2}$ (Tabela 2).

Tabela 2 - Tipos de cômodos e áreas por tipologia de habitação no Residencial San Basilio

\begin{tabular}{c|c|c|c|c|c|c}
\hline TIPOLOGIAS ARQUITETÔNICAS & $\mathbf{m}^{\mathbf{2}}$ & varanda & sala & dormitório & banheiro & cozinha \\
\hline Tipologia 01 & 39,3 & 01 & 01 & 02 & 01 & 01 \\
Tipologia 02 & 52,8 & 01 & 01 & 03 & 01 & 01 \\
\hline
\end{tabular}

Fonte: Produzida pela autora.

Antes da reabilitação, os blocos residenciais estavam configurados com dezesseis apartamentos, cada pavimento abrigava quatro unidades habitacionais. As unidades apresentavam em cada pavimento duas tipologias distribuídas de maneira espelhada. A lavanderia era coletiva e estava localizada na laje de cobertura do edifício. Os acessos eram realizados somente por escadas (Figuras 6 e 7).

Figura 6: Planta original do pavimento tipo nos Edifícios do San Basilio.

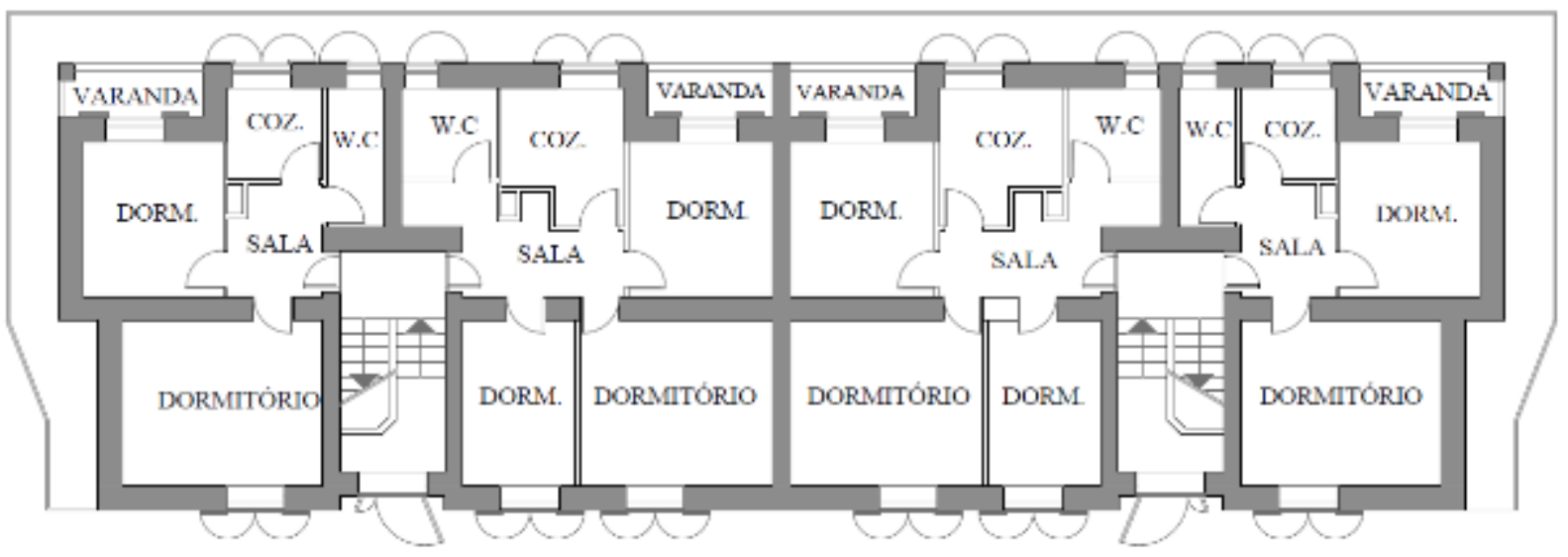

PLANTA PAVIMENTO TIPO

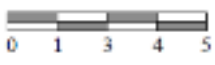

Fonte: Martins (2016).

Figura 7 - Planta da Cobertura e área de serviço coletiva do Residencial San Basilio, antes da reabilitação.

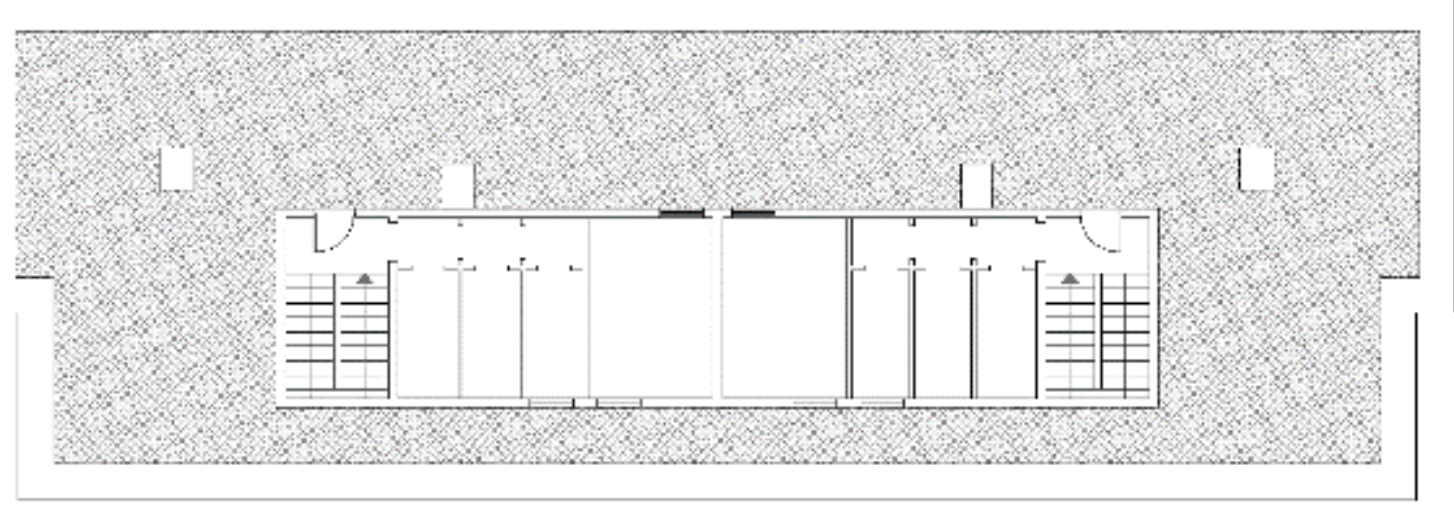

PLANTA AREA DE SERVIÇO E COBERTURA

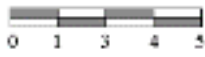

Fonte: ATER - Roma (2015). 
Nos anos 70 e 80, devido à falta de manutenção dos edifícios e ausência de serviços de suporte social público, deu-se início um processo de degradação do Residencial. As janelas de madeira e o telhado dos edifícios se deterioraram com a ação das chuvas, provocando grandes estragos no interior dos apartamentos como infiltrações e mofos. As instalações hidráulica e elétrica apresentaram problemas pela falta de manutenção e já não eram suficientes para atender a demanda do edifício. As áreas livres entre os blocos dos edifícios estavam abandonadas e eram utilizadas como depósito para entulhos. As figuras 9 e 10 mostram o estado degradado que os edifícios atingiram antes da reabilitação.

Após leitura da área e, segundo o plano de intervenções urbanísticas de Roma (art. 11 da Lei 493/93), ficou definido que o edifício adjacente à Via Recanati não seria reabilitado, pois a lei supracitada previa a ampliação desta Via, atingindo a área deste edifício o qual deveria ser demolido (Figura 08).

Segundo relato adquirido por meio da entrevista na ATER-Roma, não seria financeiramente viável recuperar este edifício para demoli-lo pouco tempo depois. Tal ação evidencia o planejamento integrado entre intervenção edilícia e intervenção urbana no Programa.

Posteriormente, as famílias deste edifício serão realocadas para outro edifício, no mesmo bairro.

Figura 8 - Planimetria geral do Residencial San Basilio, com a previsão de demolição do edifício adjacente à Via Recanati.

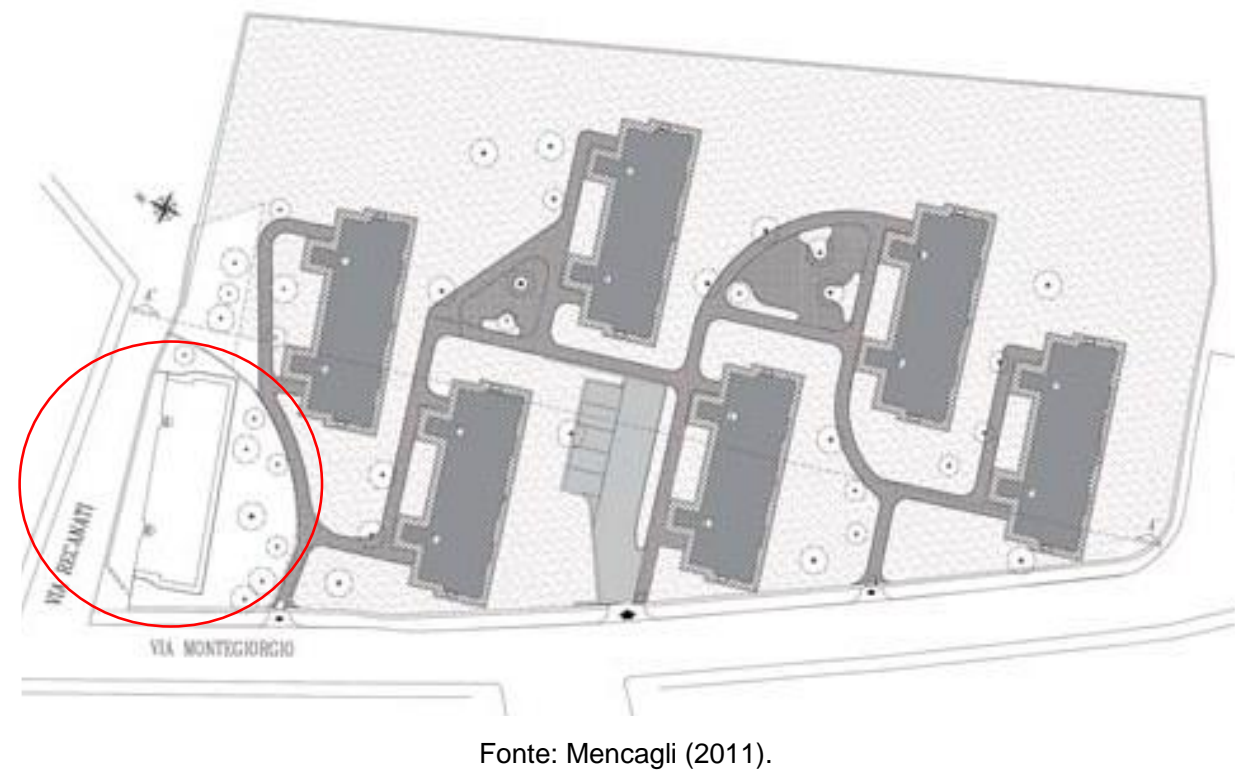

As figuras 9 e 10 mostram o edifício que será demolido e não foi reabilitado. Os outros 6 edifícios se encontravam no mesmo estado de degradação antes da reabilitação.

Figura 9: Fachada degradada antes da reabilitação.

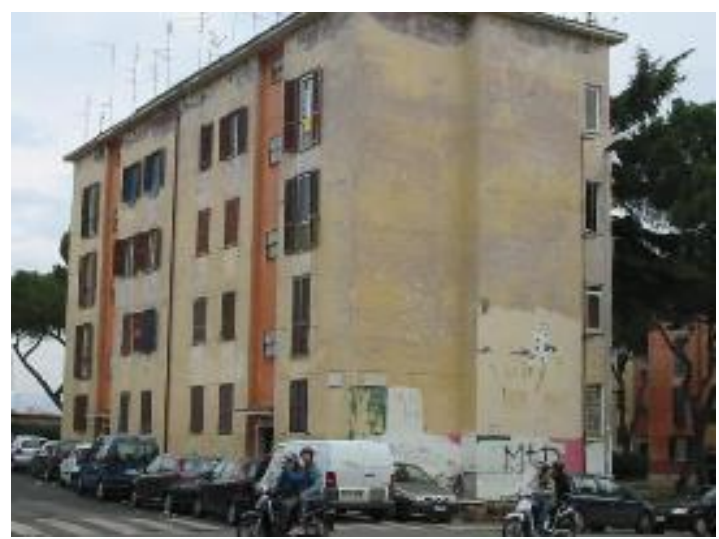

Fonte: Acervo da autora (2015).
Figura 10: Fachada degradada antes da reabilitação.

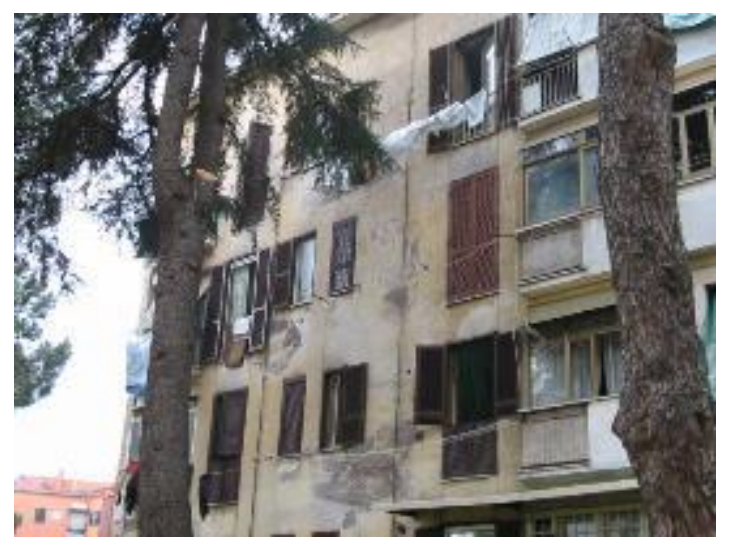

Fonte: Acervo da autora (2015). 


\section{Configuração}

Em função da área degradada, da circulação realizada somente através das escadas e dos serviços de lavanderia coletiva dos edifícios existentes no residencial San Basilio que não satisfaziam mais as necessidades atuais dos moradores, a ATER-Roma constatou a necessidade de potencializar as necessidades e expectativas sociais dos moradores. Assim, a intervenção no San Basilio, com ênfase no social, no urbano e na tecnologia moderna seria a base de partida para desenvolver um programa de requalificação para a habitação social.

Os gestores da ATER-Roma, responsáveis pela criação e desenvolvimento do projeto de reabilitação, considerando a história social, a cultura, a memória e a identidade do bairro, decidiram manter os edifícios e a população residente no mesmo local, além de buscar preservar o máximo possível os aspectos arquitetônicos dos edifícios, reabilitando-os com a criação de novos usos e formas que atenderiam as necessidades dos seus usuários.

Em 2000, o San Basilio foi reabilitado pela ATER-Roma. Atualmente, o Residencial é servido de transporte público, comércio, serviços e áreas verdes, graças à ação do PRU que não intervém apenas no edifício, mas abrange toda a área envoltória do complexo habitacional, por meio de um projeto de requalificação urbana. É um projeto completo para que a região possa se autossustentar e se desenvolver.

As tipologias dos apartamentos permaneceram as mesmas, pois os edifícios construídos originalmente com alvenaria estrutural não possibilitaram alterações nas paredes internas (retirá-las, trocar de lugar ou abrir vãos), pois poderiam comprometer a estrutura dos edifícios. A varanda recebeu fechamento para criar o espaço da lavanderia, que antes da reabilitação era coletiva (Figura 11).

Figura 11: Planta Tipo do edifico após a reabilitação.

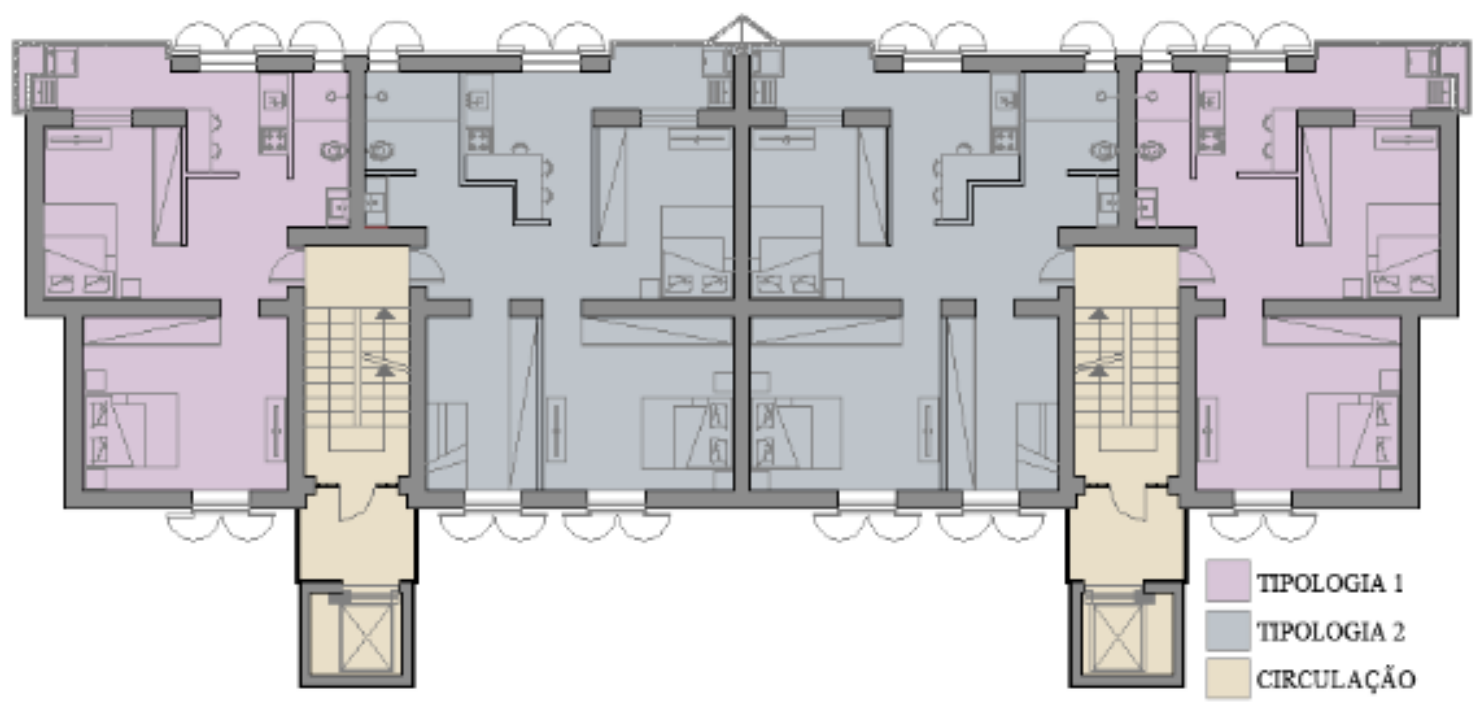

PLANTA PAVIMENTO TIPO

Fonte: Martins (2016)

Quando questionados sobre terem "perdido" a varanda do apartamento, os moradores disseram que não consideram isto um aspecto negativo da intervenção, pois os espaços abertos e coletivos do San Basilio foram requalificados e a incorporação da lavanderia dentro de cada unidade habitacional era uma exigência dos próprios moradores.

Para garantir a acessibilidade das unidades habitacionais, foram instalados elevadores anexos ao corpo do edifício. Os blocos de elevadores foram construídos com estrutura independente de modo que, se houver a necessidade de retirá-los deste contexto, a tipologia arquitetônica dos edifícios não sofrerá nenhum prejuízo estético, mantendo suas características originais (Figuras 12 e 13). 
Martins, J. C.; Salcedo, R. F. B.

Figura 12: Edifício reabilitado.

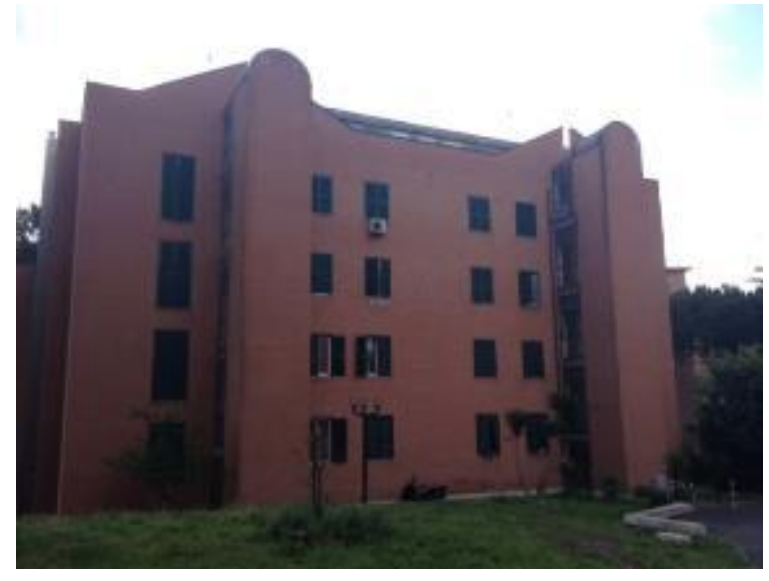

Fonte: Acervo da autora (2015).
Figura 13: Edifício reabilitado.

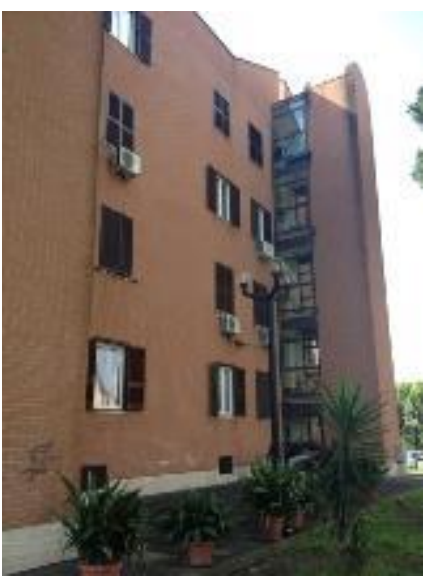

Fonte: Acervo da autora (2015).

Foram recuperadas as esquadrias de madeira que estavam em mau estado de conservação.

Algumas, ao longo do tempo haviam sido substituídas pelos próprios moradores por esquadrias metálicas, no entanto, o projeto previu a reposição dessas esquadrias por outras (novas) que pudessem recompor as características originalidade do edifício.

Foram substituídos todos os sistemas de energia elétrica, água, esgoto e aquecimento dos apartamentos, pois o sistema antigo gerava maior gasto de energia, o que não é interessante, sobretudo em se tratando de um projeto destinado à população de baixa renda, cujas condições econômicas para a manutenção e despesas mensais com a moradia são limitadas.

A materialidade construtiva original dos edifícios não garantiam as condições mínimas de conforto necessário dentro dos apartamentos, tampouco contemplava sistemas que pudessem diminuir o consumo de energia previsto na norma vigente DPR 412/93, que coloca em primeiro plano a necessidade de reduzir o consumo de energia dispersa pelo edifício.

A solução foi a implantação de um sistema de captação de energia solar nas paredes externas (por meio de placas metálicas) e na laje de cobertura, por meio de painéis de poliuretano de alta densidade, colocados diretamente sobre a estrutura de laje.

As placas metálicas fecharam as varandas e as isolaram termicamente com aplicação de painéis constituídos de duas folhas de lâmina de alumínio e entre elas um estrado de poliestireno. Os painéis captam a radiação solar para aquecimento da água no edifício.

Além disso, se posteriormente for proposto o retorno das varandas, basta retirar os painéis e a composição arquitetônica original reaparece (Figuras 14 e 15). Essa configuração segue as recomendações de intervenções no patrimônio arquitetônico proposto por Brandi (2000) que trata da utilização de materiais de fácil remoção de forma a permitir futuras intervenções².

Figura 14: Fechamento das varandas com placas de alumínio após a reabilitação do San Basilio

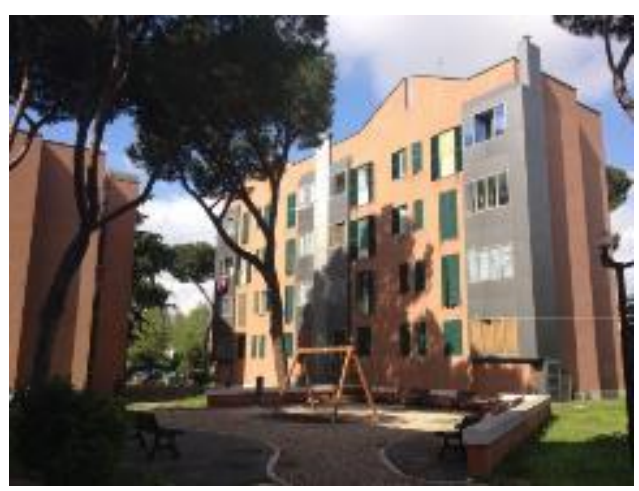

Fonte: Acervo da autora (2015).
Figura 15: Detalhe das placas metálicas usadas para fechamento das varandas no San Basilio.

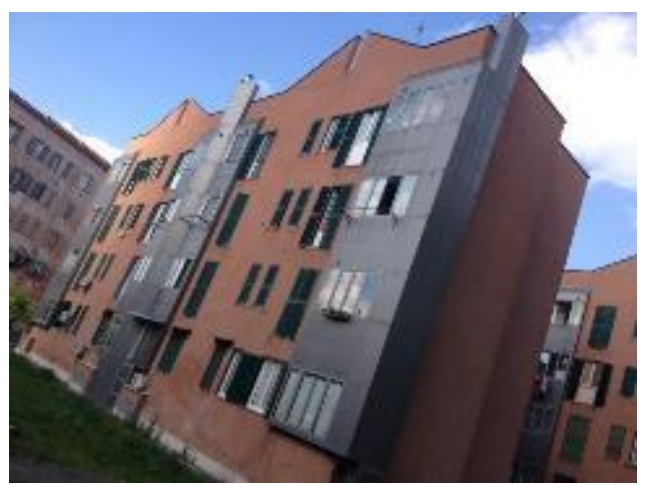

Fonte: Acervo da autora (2015). 
As paredes externas de alvenaria foram revestidas com uma categoria de gesso que fornece isolamento térmico e acústico, substituindo o reboco de cimento que estava deteriorado.

O interior das unidades habitacionais foi recuperado, substituídos os pisos e as louças sanitárias.

O gesso isolante é protegido por um revestimento (cortina de tijolos) com uma espessura de $1 \mathrm{~cm}$ que desenvolve as funções de proteção e acabamento, mantendo a transpiração da parede (Figuras 16, 17 e 18).

Como relatado anteriormente, o PRU recebe verba tanto do setor público (verbas municipais, regionais e federais) quanto do setor privado.

De acordo com os gestores da ATER-Roma, a cada dois anos realiza-se um Censo para comprovar o valor da renda das famílias beneficiadas pelo Programa, assim, faz-se um reajuste das prestações para mais ou para menos. Tal critério mostra a importância de se manter uma fiscalização pós-ocupação.

Quanto à distribuição dos apartamentos, esta ocorre de acordo com o número de pessoas que compõe as famílias.

Figura 16 - Fachada Leste do projeto de reabilitação do Residencial San Basilio.

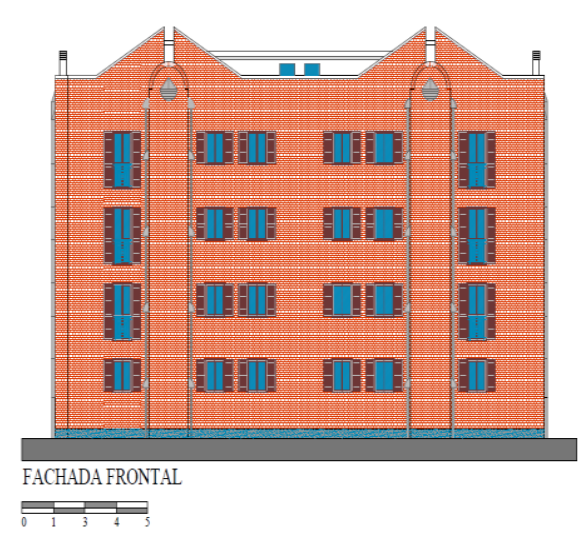

Fonte: ATER - Roma (2015)
Figura 17 - Fachada Oeste do projeto de reabilitação do Residencial San Basilio.

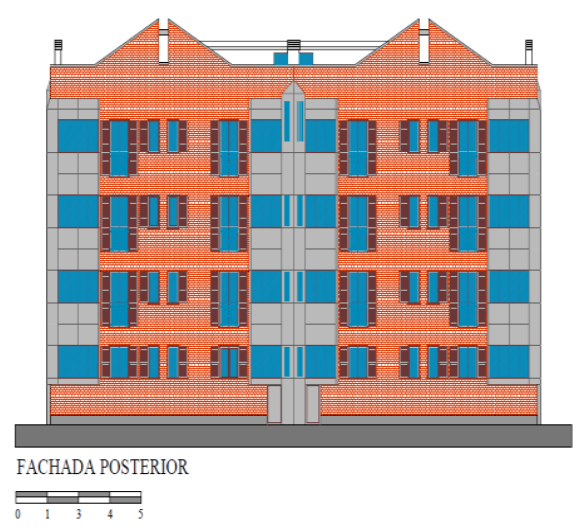

Fonte: ATER - Roma (2015).
Figura 18 - Fachada Lateral do projeto de reabilitação.

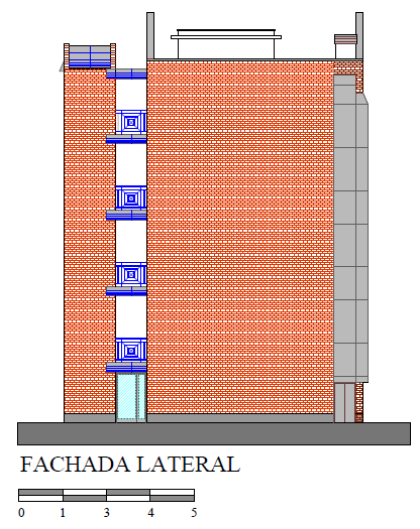

Fonte: ATER - Roma (2015).

\section{Refiguração}

Foram aplicados questionários com os moradores do Residencial San Basilio para entender o grau de satisfação com relação à unidade habitacional, pois como indicam os teóricos que fundamentam o método dialógico, uma construção só tem qualidade quando dialoga entre si a arquitetura, o entorno e o usuário. Esses três elementos devem estar em equilíbrio (dialogar) para que se possa obter qualidade de vida no ambiente construído. Portanto, a opinião dos moradores é fundamental para avaliação da qualidade do programa.

Seguem algumas das respostas:

Quando questionados sobre a importância de morar no San Basilio, todos dos entrevistados disseram estar habituados com o bairro, sentem-se seguros e não pensam em se mudar.

Quando perguntados sobre o que eles gostam e o que não gostam na arquitetura do Edifício após a reabilitação, a maioria dos entrevistados $(75 \%)$ gosta do volume que a caixa do elevador criou na fachada do edifício, dizem que "deixou o prédio bonito".

Quando perguntados se a qualidade de vida melhorou ou piorou depois da intervenção no edifício, $100 \%$ dos entrevistados disseram que a situação melhorou, porque antes da intervenção eles estavam vivendo em uma situação de completo abandono "os apartamentos estavam caindo aos pedaços, tinha infiltração, chovia dentro dos apartamentos localizados no último pavimento, tinha mofo nas paredes e as instalações elétricas apresentavam muitos problemas". "Agora, não temos mais problemas com a chuva, as instalações foram refeitas, ganhamos um espaço de lazer e temos os elevadores que facilitou a nossa vida", relataram os moradores.

Sobre a área construída por habitante nos apartamentos, $70 \%$ disseram que se sentem confortáveis, os demais reclamaram do tamanho da cozinha dizendo que "é pequena". 
Essa maioria satisfatória é resultado da distribuição dos apartamentos em função do número de membros por família, fazendo com que compartilhem, no máximo, um dormitório para cada dois residentes, e isso acontece porque as famílias são consultadas no período de projeto.

\section{CONSIDERAÇÕES FINAIS}

Diante da fundamentação teórica e do estudo de caso apresentado, pode-se inferir que a reabilitação de edifícios ociosos e/ou abandonados nas áreas centrais das nossas cidades seria uma estratégia política, social e urbana eficiente, pois além de cumprir com a função social da propriedade, atende a demanda por habitação de uma grande parcela da população de baixa renda, excluída dos meios normais de compra e financiamento imobiliário, diminui consideravelmente o déficit habitacional que existe atualmente, além de preservar o patrimônio arquitetônico e a ambiência dos centros urbanos.

Através da experiência do consolidado caso italiano, podemos agregar os seguintes aspectos às experiências de produção habitacional brasileira:

1. Priorizar a reabilitação de edifícios em áreas consolidadas, servidas de infraestrutura urbana em detrimento de novas moradias nas periferias das cidades;

2. Atuar por meio de um conjunto de ações coordenadas, fundamentadas sobre as temáticas da urbanização, o meio ambiente e o meio edilício;

3. Priorizar a acessibilidade urbana nos empreendimentos;

4. Promover a qualidade da paisagem urbana através da inclusão de mobiliário urbano, preservação de áreas verdes e recuperação de edifícios;

5. Estabelecer parcerias público-privadas para que os recursos financeiros sejam maiores e a fiscalização efetiva;

6. Os programas brasileiros não devem continuar atuando pontualmente nos edifícios. O caso italiano mostra os ganhos físicos da cidade e psicológicos da população ao estender o programa para um projeto de requalificação urbana e não apenas a reabilitação de edifícios;

7. Implantar sistemas de captação de energia solar, coleta de água pluvial, instalação de materiais termoacústicos, ou seja, usar a tecnologia na construção;

8. Participação das famílias no projeto;

9. Acompanhamento das famílias pós-ocupação;

10. Estabelecer e priorizar o diálogo entre o edifício, o entorno e os moradores.

Em suma, a atuação do Programmi di Recupero Urbano (PRU) através do Residencial San Basilio, expõe a estrutura das relações dialógicas que deve existir no planejamento público para a promoção do desenvolvimento urbano e social e também no que diz respeito a habitação popular em nossas cidades, confirmando o que Bakthin, Ricoeur e Muntañola defendem ao dizer que somente a partir dessa relação dialógica (o edifício que se conecta integralmente com a cidade e ambos se conectam integralmente aos usuários desses espaços), as nossas cidades se tornarão de fato mais democráticas e justas.

\section{REFERÊNCIAS}

ATER, R. Azienda Territoriale ed Edilizia Residenziale. Dipartimento VI di Politiche della Programmazione e Pianificazione del Territorio - Roma Capitale, 2015.Disponível em: http://www.aterroma.it/.

BAKHTIN, M. M. Estética da criação verbal. Tradução do russo por Paulo Bezerra. 4ํㅡㄹ. Ed. São Paulo: Martins Fontes, 2003.

BARRIENTOS, M. I. G. G. ; QUALHARINI, E. L. Intervenção e reabilitação nas edificações. In : CONGRESSO DE ENGENHARIA CIVIL, 5., 2002, Juiz de Fora. Anais... Rio de Janeiro : Interciências, 2002.

BRANDI, C. Teoria da restauração. Tradução Beatriz Mugayar Kühl. Cotia, SP: Ateliê Editorial, 2004.

BONDUKI, N. Os Pioneiros da Habitação Social: Cem Anos de Política Pública no Brasil. nº 1. Editora Unesp y SESC. São Paulo, 2014.

CENSIS ; FEDERCASA. Social housing e Agenzie Pubbliche per La casa. Dexia Crediop, Roma 2008. Disponível em: www.federcasa.it; istat, censimento Della popolazione e delle abitazioni, 2001.

CROITOR, E. P. N. A gestão de projetos aplicada à reabilitação de edifícios: estudo da interface entre projeto e obra. Dissertação (Mestrado) - Escola Politécnica da Universidade de São Paulo. São Paulo, 2008.

EUROCONSTRUCT CONFERENCE, 61., 2006, Amsterdam. Press release. EIB Economisch Institut Voor de Bouwnjverheid. Amsterdam, 2006. Disponível em : http://www.euroconstruct.org/ec/conference/past_events 
Martins, J. C.; Salcedo, R. F. B.

GHIONE, R. Cidade Democrática. Instituto de Arquitetos do Brasil. IAB, 2014. Disponível em: http://www.iab.org.br/artigos/cidade-democratica. Acessado em: 18/02/2018.

GUTIÉRREZ, R. História, Memória e Comunidade: o direito ao patrimônio Construído. In: SECRETARIA MUNICIPAL DE CULTURA/ DPH. (São Paulo) O direito à memória: patrimônio histórico e cidadania. Prefeitura Municipal de São Paulo: DPH, 1992. p. 121-127.

IBGE, Instituto Brasileiro de Geografia e Estatística. Anuário estatístico do Brasil. 2010. Disponível em: <http://www.ibge.gov.br>. Acesso em: 09 nov. 2013.

JESUS, C. R. M. Análise de custos para reabilitação de edifícios para habitação. 2008. 178 f. Dissertação (Mestrado em Engenharia Civil) - Escola Politécnica da Universidade de São Paulo, Departamento de Engenharia Civil e Urbana, São Paulo, 2008.

LABINUR, 2005. Estatuto das Ciddes. Disponível em :http://www.fec.unicamp.br/ labinur/Estatuto_comp.html

MARTINS, J. C. Habitação social em centros urbanos consolidados: análise dialógica desde o percurso do projeto ao uso social: São Paulo (Brasil) e Roma (Itália). Dissertação (Mestrado)- Faculdade de Arquitetura, Artes e Comunicação FAAC - Universidade Estadual Paulista - UNESP, Bauru, 2016.

MENCAGLI, P. Housing Sociale: un progetto pilota per l'ATER San Basilio. Ponte - n. 11. Roma. 2011.

MUNTAÑOLA, J. Topogénesis. Fundamentos de una nueva arquitectura. Barcelona. Edicions UPC, 2000.

Hacia uma aproximación dialógica a la arquitectura contemporânea. In : Revista Arquitectonics, Mind, Land \& Society. Arquitectura y dialogia, no 13. Barcelona: Edición UPC, mayo de 2006.

Las formas del tiempo. Serie Arquitectura. Badajoz, España: Editora @becedario, 2007.

RICOEUR, P. Arquitectura y narratividad. In: Revista Arquitectonics. Mind, Land \& Society, no 4. Barcelona:UPC, $2003, \mathrm{p}$. 9-29.

ROLNIK, R. Pensar a Cidade como Lugar para Todos. Entrevista para Revista Getúlio. São Paulo: ano 1, setembro, 2007. Disponível em: http://www.fec.unicamp.br/ labinur/Estatuto.htm

SILVA, R. R. Requisitos para projetos de requalificação de edificações preservadas: um estudo de caso na Cinelândia. Dissertação (Mestrado). Universidade Federal do Rio de Janeiro (UFRJ), Rio de Janeiro, 2004.

TRUSIANI, E. Il recupero urbano dall adeguamento allá transformazione. Editora: ARACNE -1ª edição, Roma - Itália. 1999.

VIEGAS, C. C. L. ; TEIXEIRA, R. B. O papel da ambiência histórica nos processos de tombamento de sítios históricos urbanos. Cadernos de História, Belo Horizonte, v. 18, n. 28, 1ํㅗㅇ. 2017.

\section{NOTAS}

${ }^{1}$ De acordo com Jean Paul Thibaud (2004), as ambiências são carregadas de conteúdos físicos, sociais, culturais, de uso, temporalidade, entre outros, que operam de modo inconsciente na medida em que se constroem nas relações cotidianas; associando os aspectos imateriais à espacialidade enquanto aspecto material. Gleice Elali (2013) acrescenta que esses fatores visíveis e invisíveis impregnam um determinado lugar e definem sua identidade, influenciando o comportamento das pessoas que vivem ou percorrem o local, e Peter Zumthor (2009), ao dissertar sobre "atmosferas", também acrescenta reflexões sobre ambiências ao se referir a um ambiente que se comunica com as pessoas, suas emoções e a vizinhança, e que provoca um sentimento que contagia e, de modo instintivo, ajuda o ser humano a sobreviver. Em suma, percebemos que as ambiências são geradas pela subjetividade, na medida em que as pessoas interagem com o ambiente (VIEGAS \& TEIXEIRA, 2017).

2 No entanto, se nos basearmos nas formas adequadas para intervenção no patrimônio arquitetônico, nota-se que esses edifícios não foram vistos como tendo um valor patrimonial em sua totalidade, pois dada a transformação figurativa dos mesmos, apesar de haver o cuidado na reversibilidade de partes da intervenção, como no fechamento da varanda, a intervenção no coroamento do edifício não é reversível e transforma substancialmente o edifício.

* Agradeço à Fundação de Amparo à Pesquisa do Estado de São Paulo (FAPESP), processo nº 2014/00299-9 pelo suporte.

NOTA DO EDITOR (*) O conteúdo do artigo e as imagens nele publicadas são de responsabilidade do(s) autor(es). 